\title{
ANALISIS PENGARUH KINERJA ORGANISASI LPD BANYUALIT TERHADAP TINGKAT KEPERCAYAAN NASABAH
}

\author{
Luh Asih Utami, Ni Kadek Siska Rismala Dewi, \\ Ida Ayu Reindivtia, Komang Desy Kristina \\ Jurusan Akuntansi, Universitas Pendidikan Ganesha, Singaraja, Bali, Indonesia
}

\begin{abstract}
Abstrak
Penelitian ini bertujuan untuk mengetahui apa yang mendasari LPD Desa Adat Banyualit saat ini memperoleh kepercayaan kembali dari nasabah, bagaimana perbedaan kinerja LPD Desa Adat Banyualit sebelumnya dengan LPD Desa Adat Banyualit saat ini. Dalam penelitian ini menggunakan metode kualitatif. Penelitian ini menggunakan tiga teknik pengumpulan data, yakni wawancara, dan observasi. Dalam metode wawancara peneliti melakukan wawancara kepada beberapa nasabah dan pengurus LPD Banyualit. Nasabah LPD Banyualit mempercayai kembali untuk menabung dan meminjam di LPD Banyualit karena cara kerja dan staf yang berbeda dengan yang sebelumnya. LPD Banyualit yang sekarang lebih mempermudah masyarakat sehingga niat masyarakat meningkat baik itu dari desa setempat maupun luar desa
\end{abstract}

Kata kunci: LPD, Kepercayaan, Kinerja

\begin{abstract}
This study aims to find out what underlies the LPD of the Banyualit Desa now gaining trust from customers, how is the difference in the performance of the LPD of the Banyualit Desa before the LPD of the Banyualit Desa. In this study using qualitative methods. This study uses three data collection techniques, namely interviews and observation. In the interview method the researcher conducted interviews with several customers and administrators of the Banyualit LPD. Banyualit LPD customers trust again to save and borrow in the Banyualit LPD because of the way they work and staff are different from the previous one. The Banyualit LPD now makes it easier for the community so that the community's intentions increase both from the local and outside villages
\end{abstract}

Keywords : LPD, Trust, Performance

\section{Pendahuluan}

Konflik internal yang dialami LPD Banyualit, kecamatan Buleleng benar - benar membuat LPD yang berada dikawasan wisata lovina itu sulit mendapatkan kepercayaan masyarakat. Sebelum munculnya konflik tersebut dinyatakan pihaknya rutin melakukan pembinaan teknis manajemen yang dijalankan pengurus LPD berdasarkan Standar Operasional Prosedur ( SOP ). Namun pembinaan dan saran - saran yang diberikan tampaknya tidak dijalankan. Pada hasil pembinaan sebelumnya pihak LPD menemukan kesalahan manajemen, sehingga menimbulkan permasalahan yang melilit LPD Banyualit. Selain itu peran Badan Pengawas di internal lembaga juga dinilai tidak optimal, Padahal sesuai fungsinya, badan pengawas ini mengawasi kinerja pengurus dan pengurus melakukan hal-hal yang melenceng dari ketentuan seharusnya cepat diingatkan. Sehingga permasalahan tidak sampai mencuat. Pada tahun 2013 lalu LPD Banyualit dinyatakan kolaps akibat ulah ketua LPD Desa Banyualit tersebut yang dinyatakan korupsi hingga Rp9 Miliar. Dan pada saat itu nasabah banyak yang melakukan demo terhadap LPD Banyualit dan sudah melaporkan ketua LPD kepada pihak kepolisian. Namun pada 2014 lalu krama desa Banyualit berusaha bangkit dari keterpurukan yang dialami LPD dan sudah membentuk pengurus baru, namun masyarakat tidak ada lagi yang tertarik untuk menabung atau mendepositokan dana lebih miliknya.

Pada 2017 lalu karma desa adat Banyualit Membangkitkan kembali LPD Banyualit tersebut karena selama ini perekonomian Desa Pakraman Banyualit seolah mati suri akibat tidak berjalannya LPD. Dengan itu muncullah inisiatif dari pengurus untuk membangkitkan kembali LPD tersebut. Keberadaan LPD ini tidak ada hubungan dengan LPD sebelumnya. 
Meski, LPD sebelumnya masih ada asset yang tercecer. Namun menurut pengurus, tu akan terakomodir kembali setelah dana-dana terkumpul. LPD Banyualit ini dimulai dari nol dan kembali membuat peraturan baru. Selain itu uang nasabah yang dikorupsi sebelumnya direncanakan akan dikembalikan dan pengurus optimis LPD Banyualit saat ini akan berjalan lancar.

Berdasarkan masalah diatas, adapun rumusan masalah yang dilakukan yaitu apa yang mendasari LPD Desa Adat Banyualit saat ini memperoleh kepercaan kembali dari nasabah, bagaimana perbedaan kinerja LPD Desa Adat Banyualit sebelumnya dengan LPD Desa Adat Banyualit saat ini.

\section{Metode \\ Desain Penelitian}

Dalam penelitian ini menggunakan metode kualitatif. Penelitian kualitatif merupakan penelitian yang digunakan untuk menghasilkan data deskriptif yang ditulis atau yang diucapkan orang dan perilaku - perilaku yang dapat diamati ( Bigdan dan Taylor (1975) dalam Pawito, 2008 ).

\section{Lokasi Penelitian}

Lokasi penelitian ini adalah LPD Desa Adat Banyualit, Kecamatan Bulelelng.

\section{Objek dan Subjek Penelitian}

Objek dalam penelitian ini mengambil data pengaruh kinerja organisasi LPD Desa Adat Banyualit terhadap kepercayaan nasabah. Subjek dalam penelitian ini adalah pihak internal LPD Desa Adat Banyualit dan Nasabah dari LPD Desa Adat Banyualit.

\section{Sumber Data}

Dalam penelitian ini sumber data yakni bebera nasabah dari LPD Desa Adat Banyualit dan Pengurus LPD Desa Adat Banyualit yang disebut dengan informan yang akan disamarkan nama - namanya yang akan diwawancara.

\section{Teknik Pengumpulan Data}

Dalam penelitian ini menggunakan tiga teknik pengumpulan data, yakni wawancara, dan observasi.

1. Metode Wawancara yang digunakan dalam penelitian ini wawancara terstruktur, yang mana peneliti sudah mempersiapkan pertanyaan - pertanyaan yang akan dijawab oleh narasumber atau informan. Dalam hal ini peneliti melakukan wawancara kepada bebrapa nasabah dan pengurus LPD Banyualit.

2. Observasi merupakan bagian dalam pengumpulan data yang langsung dari lapangan, yang mana dalam penelitian ini melakukan observasi ke narasumber untuk bertatap muka dalam melakukan wawancara dan melihat langsung LPD Banyualit.

\section{Hasil dan Pembahasan}

\section{YANG MENDASARI LPD BANYUALIT SAAT INI MEMPEROLEH KEPERCAYAAN KEMBALI DARI NASABAH}

Pada tahun 2013 lalu LPD tersebut sempat kolaps akibat ulah Ketua LPD Desa Adat Banyualit, Gede Budiasa yang melakukan korupsi hingga Rp9 Miliar. Akibat dari korupsi yang dilakukan oleh Gede Budiasa yang pada saat itu menjabat sebagai Ketua LPD Desa Adat Banyualit segala kegiatan dan operasional dari LPD Desa Adat Banyualit ini menjadi kacau dan menyebabkan kebangkrutan, karena kasus yang terjadi di LPD Desa Adat Banyualit tersebut menyebabkan tingkat kepercayaan masyarakat terhadap LPD Desa Adat Banyualit tersebut menurun. Akibat dari bangkrutnya LPD Desa Adat Banyualit ini juga dirasakan oleh masyarakat setempat seperti yang telah disampaikan oleh Kelian Desa Pakraman Banyualit, Jro Ketut Widarta mengatakan, selama ini perekonomian Desa Pakraman Banyualit seolah mati suri akibat tidak berjalannya LPD. Namun dengan rasa jengah, muncul inisiatif dirinya bersama krama untuk membangkitkan kembali keberadaan 
LPD di Desa Pakraman Banyualit. Jro Ketut Widiarta mengatakan, "LPD ini harus dibangun kembali, dengan rasa jengah karena LPD merupakan lumbung Desa Pakraman untuk dapat membangun perekonomian Desa Pakraman. Tanpa LPD, saya yakin Desa Pakraman tidak jalan karena banyak kepentingan adat yang memerlukan keberadaan LPD," kata Widarta.

Seperti yang disampaikan bahwa LPD Desa Pakraman Banyualit ini dimulai lagi dari nol. Dimana biaya operasional belum ada. Untuk dapat memenuhi operasional LPD ini, maka diperlukan dana segar yang tidak sedikit. Krama pun diminta kesukarelaannya untuk menyisihkan dananya untuk operasional LPD. Itupun belum mampu mencukupi. Saat situasi sulit itu, munculnya "juru selamat" atau "malaikat penyelamat" bernama DR Putu Bagiada, MM. Mantan Bupati Buleleng yang juga kini menetap di wilayah itu langsung menyetor dana pribadinya sebesar Rp 30 juta dalam bentuk tabungan. Uang sebesar itu disetorkan langsung secara tunai saat paruman yang dilakukan. Widarta pun mengaku bersyukur dengan bantuan dana segar dari mantan pemimpin Buleleng tersebut. Dengan bantuan itu, ia optimis bahwa LPD ini akan berkembang dengan pesat. Pada saat ratusan krama Desa Adat Pakraman Banyualit menggelar paruman di Pura Desa Pakraman Banyualit, Kamis (1/6/2017) disetujui bahwa hari Lahirnya Pancasila ditetapkan sebagai tanggal kelahiran LPD tersebut. Dengan adanya keseriusan dari pihak internal Desa Pakraman Banyualit ini membuat masyarakat mulai memberikan kepercayaan mereka terhadap LPD Banyualit ini dan mau ikut serta dalam membangun LPD Banyualit tersebut. Hal yang juga mendasari masyarakat percaya untuk bergabung ke LPD Banyualit tersebut karena masyarakat percaya dengan berubahnya struktur kepemimpinan dan organisasi di LPD Banyualit tersebut juga merubah sistem atau kinerja dari LPD Banyualit tersebut. Serta pemilihan untuk bergabung di LPD Banyualit tersebut dikarenakan lokasi yang dekat dan memang masyarakat disana disarankan untuk ikut bergabung guna membangun LPD tersebut agar dapat hidup seperti sebelumnya.

\section{PERBEDAAN KINERJA PENGURUS MAUPUN MANAJEMEN LPD BANYUALIT TERDAHULU DENGAN SAAT INI}

Perbedaan yang terjadi pada LPD Banyualit ini terlihat dari segi sistemnya. Diketahui bahwa dahulu LPD Banyualit masih menerapkan sistem manual dengan melalukukan pencatatan data secara manual yang menyebabkan jalannya kegiatan transasksi di LPD Banyualit ini menjadi cukup lama sehingga masyarakat mengeluh bahwa waktu mereka habis untuk mengantri ketika hendak melakukan transaksi di LPD Banyualit tersebut. Namun pada kepemimpinan LPD Banyualit setelah kebangkrutan ini sudah mengubah sistemnya menjadi lebih modern yaitu tidak menggunakan cara manual seperti yang dilakukan sebelumnya melainkan dalam mencatat data transaksi yang dilakukan sudah menggunakan computer sebagai media pembantu sehingga kinerja dari LPD Banyualit ini berjalan lebih cepat dan masyarakat mengaku sudah tidak perlu mengantri lebih lama lagi.

Dengan adanya sistem baru yaitu penggunaan computer diharapkan pengurus atau pegawai dari LPD Banyualit tersebut meminimalisir resiko terhadap kecurangan pencatatanpencatatan yang semulanya hanya ditulis manual dan akan lebih mudah memeriksa kekeliruan pencatatan yang terjadi. Selain itu, konflik internal yang dialami LPD Banyualit pada masa lalu dikarenakan kinerja manajemen dan organisasinya yang kurang terorganisir menyebabkan masalah yang terjadi semakin berlarut-larut. Namun saat ini LPD Banyualit sudah melakukan penilaian kinerja terutama pegawainya jika memiliki masalah agar langsung mendiskusikannya agar masalah tersebut cepat menemukan titik terang atau solusi. Dengan adanya komunikasi yang baik antara internal dan eksternal (nasabah) menjadikan LPD Banyualit saat ini kembali memperoleh kepercayaan dari masyarakat.

\section{Simpulan dan Saran Simpulan}

Dari penelitian yang dilakukan maka disimpulkan bahwa Nasabah percaya lagi untuk menabung dan meminjam di LPD Banyualit karena cara kerja dan staf yang berbeda dengan yang sebelumnya. LPD Banyualit yang sekarang lebih mempermudah masyarakat sehingga niat masyarakat meningkat baik itu dari desa setempat maupun luar desa. 


\section{Saran}

Berdasarkan kesimpulan penelitian, maka peneliti dapat memberikan saran, yaitu masyarakat sebaiknya harus memberikan respon positif, karena hal tersebut dapat menguntungkan jika terlaksana dengan baik. Pihak LPD seharusnya meningkatkan sumber daya dan menjaga kepercayaan dari nasabah.

\section{DAFTAR PUSTAKA}

Bali Editor.com . 1 Juni 2017 . Keuangan: LPD Banyualit Bangkit Kembali, Mantan Bupati Bagiada Tabung Rp 30 Juta (online). Terdapat pada (http://balieditor.com/keuanganIpd-banyualit-bangkit-kembali-mantan-bupati-bagiada-tabung-rp-30-juta/, diakses pada 02 Desember 2018).

Course Hero. - . 2 Pengertian Fungsi Tujuan Dan Bidang Usaha LPD 21. Diakses pada 04 Desember 2018,https://www.coursehero.com/file/p487ras/2-Pengertian-FungsiTujuan-dan-Bidang-Usaha-LPD-21-Pengertian-LPD-Lembaga/

KabarNusa.com . 1 Juni 2017 . Kucurkan Rp30 Juta, Mantan Bupati Buleleng Bangkitkan LPD Banyualit (online). Terdapat pada (https://www.kabarnusa.com/2017/06/kucurkan-rp30-juta-mantan-bupati.html, diakses pada 02 Desember 2018).

Gunawan, Ketut. 2009. Analisis Faktor Kinerja Organisasi Lembaga Perkreditan Desa di Bali (Suatu Pendekatan Perspektif Balanced Scorecard) JURNAL MANAJEMEN DAN KEWIRAUSAHAAN, VOL.11, NO. 2, SEPTEMBER 2009: 172-182. Terdapat pada (https://www.academia.edu/23307620/Analisis_Faktor_Kinerja_Organisasi_Lembaga _Perkreditan_Desa_di_Bali_Suatu_Pendekatan_Perspektif_Balanced_Scorecard, diakses pada 04 Desember 2018).

Makplus, Om. 15 Juli 2015. Definisi dan Pengertian Menurut Ahli (online). Terdapat pada (http://www.definisi-pengertian.com/2015/07/kinerja-organisasi.html, diakses pada 20 Desember 2018).

Sumarwan, Ujang. 2011. Perilaku Konsumen: Teori dan Penerapannya dalam Pemasaran, Ghalia Indonesia, Bogor, hlm. 165-166. Terdapat pada (https://www.google.co.id/url?sa=t\&rct=i\&q=\&esrc=s\&source=web\&cd=1\&cad=ria\&ua ct=8\&ved=2ahUKEwiX7vec7 HfAhUHvl8KHYCYDGkQFiAAegQIChAC\&url=http\%3A \%2F\%2Feprints.stainkudus.ac.id\%2F478\%2F14\%2F5.\%2520BAB\%2520II\%2520edit .pdf\&usg=AOvVaw3CORVXTejvRPEbOkukANQX, diakses pada 10 Desember 2018) 